Rosen, Ilana. "The Poetry of 1.5 and Second-Generation Israelis of Hungarian Origin." Hungarian Cultural Studies. e-Journal of the American Hungarian Educators Association, Volume 8 (2015): http://ahea.pitt.edu DOI:

\title{
The Poetry of 1.5 and Second-Generation Israelis of Hungarian Origin
}

\section{Ilana Rosen}

\begin{abstract}
This article continues my 2014 article in this journal, in which I presented a beginning of work on contemporary Israeli prose writers of Hungarian origin. My analysis of those works showed that they are governed by recurring concerns, or literary themes, such as: the memory or post-memory of the Holocaust; Hungarian-to-Hebrew language and translation peculiarities; preoccupation with the family's past, including that of remote relatives; and fascination with home objects, dishes, and recipes representing the family's Hungarian past. Following my work on those prose works, in this article I focus on the works and worlds of 1.5 and second-generation Hungarian-Israeli poets and explore, first, the presence of the concerns or themes governing this group's prose works, and, second, issues of identity through the poets' depictions of experiences such as persecution, displacement, emigration, and re-settlement in Israel. My present discussion of the 1.5 and second-generation Hungarian-Israeli poets is divided into four themes: the Holocaust as an epitome of catastrophe, the Holocaust as memory and postmemory, co-fusion of languages and cultures, and the eternal mental displacement of the poets' parents.
\end{abstract}

Keywords: Hungarian Israelis, Poetry, Holocaust Memory, Postmemory, Second Generation Holocaust Survivors, Eli Netzer (Schnitzer), Itamar Yaoz-Keszt, Ági Mishol, Dorit Weissman

Biography: Ilana Rosen studies the documentary literature of Jews of Central Europe as well as the multi-ethnic narrative of emigration to and the foundation of the south of Israel. Her publications include: Sister in Sorrow: Life Histories of Female Holocaust Survivors from Hungary (Detroit, MI: Wayne State UP, 2008), and Soul of Saul: The Life, Narrative, and Proverbs of a Transylvanian-Israeli Grandfather (Burlington, VT: Vermont University, 2011).

This article continues my 2014 article in this journal, in which I presented a beginning of work on contemporary Israeli prose writers of Hungarian origin (Rosen 2014). In that work I first offered an inclusive and generational typology of Hungarian-Israeli writers and poets, starting from the early twentieth century up to the present, and then focused on the biographically determined prose works of a few of the 1.5 and second-generation to the Holocaust and immigration writers among them (on the "1.5. generation," see Suleiman 2002). My analysis of those works showed that they are governed by recurring concerns, or literary themes, such as: the memory or postmemory of the Holocaust or shoah (Hirsch 2012); Hungarian-to-Hebrew 
Rosen, Ilana. "The Poetry of 1.5 and Second-Generation Israelis of Hungarian Origin." Hungarian Cultural Studies. e-Journal of the American Hungarian Educators Association, Volume 8 (2015): http://ahea.pitt.edu DOI:

language and translation peculiarities; preoccupation with the family's past, including that of remote relatives; and fascination with home objects, dishes, and recipes representing the family's Hungarian past. Following my work on those prose writers and works, in this article I wish to focus on the works and worlds of 1.5 and second-generation Hungarian-Israeli poets and explore, first, the presence of the concerns or themes governing this group's prose works; and second, to examine issues of identity through the poets' depictions of experiences such as persecution, displacement, emigration, and re-settlement in Israel (on the fusion of national and personal themes in the poetry of non-Hungarian second-generation to Holocaust and immigration Israeli poets, see Fuchs 2000).

My survey of the works of the 1.5 and second-generation Israeli poets of Hungarian origin led me to focus on the following four poets, two born in Hungary, one in Romania and one in Israel. Eli Netzer (Schnitzer) was born in Budapest in 1933 and immigrated to Israel in 1949, settling in Kibbutz Dalia in the country's north. He is the founder of Maarechet ['Editorial'] Press that specializes in poetry and documentary writing and which published many works by people of Hungarian origin. Poet, prose writer, essayist, and translator Itamar (né Péter Ervin) Yaoz-Keszt was born in 1934 in Szarvas, in south-eastern Hungary, and was deported with his parents and sister Mari(ca) to Bergen Belsen, from where, luckily, they all returned. He immigrated to Israel in 1951 and married Hannah Yaoz (1935-2014), a Bar Ilan University researcher of the Holocaust theme in Hebrew literature, who has devoted some works to Itamar's Holocaust poetry (e.g., Yaoz 1984, 29-37, 59-69; see also Vardi, Dov 1981). In 1958 Itamar Yaoz-Keszt started his own literary press called Eked, a term alluding to akedalaqeda, meaning the binding of Isaac on Mt. Moriah in Genesis 22, which had become a key symbol of sacrifice in Hebrew literature. Ági Mishol was born in 1946 in Szilágycheh (Chehu silvaniei) in Erdély (Transylvania), a region that as of 1947 became part of Romania. Mishol immigrated to Israel in 1950, grew up in Gedera, a small town south of Tel Aviv, and presently lives on Kfar Mordechai village near Gedera. Dorit Weissman was born in 1950 in Kfar Sava, north of Tel Aviv, to Holocaust survivors from Hungary. In 2005, following a period of tending to and getting much closer than ever before to her dying mother, Weissman devoted to her an entire volume, Lirkod itach czárdás—preda me-em ['Dancing Czárdás with You: Poems Parting from a Mother']. In strict generational terms, the first two poets, Eli Netzer and Itamar Yaoz-Keszt, belong to the 1.5 Holocaust and immigration generation; Ági Mishol is second Holocaust generation but 1.5 generation to immigration; and Dorit Weissman is second generation to both experiences.

In my 2014 article I pointed out the scarcity of research about Israeli prose writers of Austro-Hungarian origin, but when it comes to authors who write poetry, who number about the same, this small analytic inventory shrinks even more. If one looks up the present four poets in the Ohio State University Galron-Goldschlager on-line Lexicon hasifrut haivrit hahadasha ['Lexicon of Modern Hebrew Literature'] (http://library.osu.edu/projects/hebrew-lexicon), or the Heksherim ['Contexts'] printed Hebrew Lexicon (Stavi and Schwartz 2014), one finds many publicistic and literary-supplement type critiques but very few scholarly studies, and of them even fewer written not in Hebrew, which strengthens the need for further exploration of the work of Hungarian-Israeli poets. I will henceforth analyze eleven poems written by the above listed four poets (one poem by Eli Netzer, four by Itamar Yaoz-Keszt, four by Ági Mishol, and two poems by Dorit Weissman) dividing my discussion into four themes: The Holocaust as an epitome of catastrophe, the Holocaust as memory and postmemory, co-fusion of languages and cultures, and the eternal mental displacement of the poets' parents. 
Rosen, Ilana. "The Poetry of 1.5 and Second-Generation Israelis of Hungarian Origin." Hungarian Cultural Studies. e-Journal of the American Hungarian Educators Association, Volume 8 (2015): http://ahea.pitt.edu DOI:

\section{The Holocaust as an Epitome of Catastrophe}

In this section that deals with the Hungarian-Israeli poets' pessimistic view of HungarianJewish fate I analyze two poems, one by Eli Netzer and one by Itamar Yaoz-Keszt. Eli Netzer's poem, "The Existence of Man," appears in his collection within a section titled "Writing Poetry after Auschwitz," a title which indicates that Netzer overtly echoes the much misquoted call of philosopher, sociologist, and musicologist Theodore Adorno (1903-1969) that it is impossible to write poetry after Auschwitz, by which he meant that it was necessary to invent a new way to write poetry, and not, as was mistakenly understood for decades, to cease writing poetry altogether (Adorno 1967: 19). Netzer delineates in this poem his national and family lineage and gene inventory through an assemblage of mythical and historical figures mixed together with his own rather ordinary ancestors.

"Kiyum ha-adam" ['The Existence of Man']

I carry within me the genes of Abram of Ur Kaśdim

And of Grandpa Moric Filipovic who was incinerated in Auschwitz

And of Roman and Persian soldiers

And the Cossacks of Bogdan Khmelnytsky

Who raped my grandmothers

And of [King David, I.R.] the son of Yishai who slept with

Ahinoam of Jezreel

And loved Bathsheba with a terrible love

And the genes of Sándor Schnitzer

Who was a tailor's apprentice

and who told me

My son

The existence of man is an ongoing tragedy

(Netzer 1992: 10) ${ }^{1}$

The first figure invoked within the poet's genealogy ${ }^{2}$ is the Ur Father of the Jewish nation according to the Hebrew Bible or the Old Testament. Yet the poet calls this forefather by his original name Abram and not Abraham, the later name given to him by God together with the divine promise that Abraham shall become the father of a huge nation ("Your name shall no longer be Abram but your name shall become Abraham, because I have designated you a father of many nations," Genesis 17:5). Abraham's new name holds within God's presence through the added letter "הei), which is one of God's names in the Jewish Bible. Within the twentieth century context of the loss of Abraham's children in the shoah, Netzer's return to the nation fore-

\footnotetext{
${ }^{1}$ All translations from the Hebrew are mine; I thank my colleague Chanita Goodblatt of the Ben Gurion University of the Negev for her help and advice in translation. All Hungarian terms and spelling are also mine, as in the poems they appear only in Hebrew transcription.

${ }^{2}$ Throughout this article I refer to the flesh-and blood poets and not to their abstracted personas, as customary in poetry analysis, because of the explicit personal-biographical aspects and dimensions manifested in all the poems at hand.
} 
Rosen, Ilana. "The Poetry of 1.5 and Second-Generation Israelis of Hungarian Origin." Hungarian Cultural Studies. e-Journal of the American Hungarian Educators Association, Volume 8 (2015): http://ahea.pitt.edu DOI:

father's original name by way of a rebellious omission of the divine name from it is to be read as a denouncement of God's presence and blessing to the Ur Father and to his later generations, down to the Hungarian-Jewish Filipovic-Schnitzer-Netzer family of the 1940s. Indeed, the next person in the poet's lineage is his grandfather Moric Filipovic, one of the many children of Abraham that were lost in the Holocaust, and otherwise an anonymous Hungarian every-Jew.

Having marked the ancient beginning and the modern demise of the Jewish people including his family, the poet starts moving back and forth within Jewish history, associatively skimming through episodes. Going back two thousand years from the Holocaust, he first talks of the ancient Persian and Roman Empires, whose soldiers, just like the Cossaks of Khmelnytsky in the 1648-1649 massacres, have committed anti-Jewish atrocities, including mass rape of Jewish women. Carried on by this line of associations of powerful rulers and their ruthless deeds toward women, the poet then, surprisingly, once again goes backward in time, this time landing at the court of warrior, poet, musician and King David (c. 1040-970 BC). In Biblical lore this King, his son Solomon (Shlomo), and quite a few of their successors are famed for having had several lawful wives as well as a host of formal mistresses. King David had, in addition to all these, "a terrible love" affair with Bathsheba, wife of Uriah, an army commander whom the King sent to his death in battle to legalize his adulterous relations with Uriah's wife. Given King David's complex amorous history, one needs to ask why then in this passage it is Ahinoam of Jezreel, a fairly unknown and unimportant wife of the King, who is featured. The answer is that Ahinoam is mentioned because of the matter-of-factness in which King David simply "[sleeps] with" (I Samuel 25, 43 says: "David has also taken") her along with the bride he married at that time, Abigail, daughter of his foe Nabal the Carmelite. Thus Netzer is saying that, from the point of view of many generations of Jewish women, from Biblical figures to the anonymous foremothers of the poet who have been the victims of rape, it is the brutal aggression itself that is the source of trauma, regardless of whether it was perpetrated by the enemy or by one's own kin $(\mathrm{g})$.

After talking about mostly ancient phases of his national genealogy—excluding his midtwentieth-century grandfather Moric - the poet skips many other pertinent scenes from the history of Jewish suffering to which he might have referred, from, for example, the 1492 Spanish Expulsion or the later Inquisition, or the 1882 Ukraine massacre, to the 1903 Kishinev pogrom, coming down directly to his own father, Sándor Schnitzer. Although he was a only simple Hungarian-Jewish tailor's apprentice, this man could come up with a deep philosophical conclusion to the history of the Jews and of mankind in general, saying that the existence of man, including that of woman, is a sad story, full of violence. Interestingly, besides the father's Hungarian sounding first name, there is no allusion to the family father's Hungarian identity; by contrast, in the other poems by Hungarian-Israeli poets in this article, there are recurring references to the Hungarian or Central-European background of the poets and of their parents and other relatives.

In the visionary "Route Preparations" poem of the second poet, Itamar Yaoz-Keszt, the destruction of the poet's relatively peaceful life as a Hungarian-Jewish child born in the mid1930s is only hinted at and never made explicit.

From: "Hakhanot laderekh" ['Route Preparations']

And my eyesight becomes clear:

the house-garden tarries

in the no-man's land between fact and fiction, and a mother and son who sit in the glass-porch 
Rosen, Ilana. "The Poetry of 1.5 and Second-Generation Israelis of Hungarian Origin." Hungarian Cultural Studies. e-Journal of the American Hungarian Educators Association, Volume 8 (2015): http://ahea.pitt.edu DOI:

as if in a bubble-of-crying

watch the way with pounding hearts,

wanting to know if the grass rising to the sky around the garden

is already rising on my cheeks

They call me from the depths of the oblivion of language,

they call me in the melody of a scheming children's song

still saved in the nerve-fibers:

"Csiga! Biga! My snail

How dare you not listen to me!

Your house is on fire,

Come on out, tarry not,

Csiga! Biga!

Woe is you and woe is me!"

(Yaoz-Keszt 1980: 16)

These two middle stanzas out of four in this poem feature a mother and son sitting on a glass porch, in a scene that connotes anticipation. In the first of these two stanzas it seems that what the mother and son look forward to is the expected, natural phase of the boy's physical, sexual maturity ("the grass rising [...] on my cheeks"), which may remind us of many a girls-comingof-age fairytale like "Sleeping Beauty," "Snow White," and "Cinderella," that all deal with female puberty in one way or another. But the next stanza makes clear that at stake are more fateful and far from natural processes becoming overt and real; although even now the threat is camouflaged by a seemingly innocent Hungarian children's verse - that incidentally exists in Hebrew as well—alluding to children's curiosity about "what's inside there," be it snail's shell, a house or room interior, or the body's. The Hungarian anonymous verse goes: "Csiga-biga gyere ki / ég a házad ideki / kapsz tejet, vajat / holnapra is marad" ['Silly-snail come on out / your house is on fire, hurry out / you'll get enough milk and butter /for today and tomorrow']. ${ }^{3}$

Comparing these two "Snail" texts, the Hungarian children's verse alluded to in the poem and Yaoz-Keszt's own distorted reverberation of this verse within his Hebrew poem, we see that only their very beginnings are similar in their call for the snail to flee from its burning house or shell. Following this opening, the children's verse offers comfort to the "survivor snail" in the form of homey, nourishing foods like milk and butter; whereas the verse's misrepresentation within the poem goes on ringing the bells of alarm, then expresses anger at the snail's inattentiveness, and finally ends on a woeful, lamenting note. The mention of fire, combined with the hindsight knowledge of the fate of the bulk of European Jewry in the Holocaust, inevitably evokes mournful events and shatters the poem's not-so-innocent to-start-with childish malice ("scheming") connotation. Finally, the lament-like ending makes clear-by its allusion to

\footnotetext{
${ }^{3}$ The Hebrew "Snail" verse, which seems to have no trace in Yaoz-Keszt's poem that clearly alludes only to the Hungarian verse, says: "Berale, Berale tse hahutsa / aba veima yitnu lekha uga" ['Berale, Berale, come on out / Father and Mother will give you some cake'].
} 
Rosen, Ilana. "The Poetry of 1.5 and Second-Generation Israelis of Hungarian Origin." Hungarian Cultural Studies. e-Journal of the American Hungarian Educators Association, Volume 8 (2015): http://ahea.pitt.edu DOI:

the Yiddish oy vey iz mir exclamation - that the addressor and addressee here are one and the same survivor expressing sorrow at failing to escape disaster while still possible.

\section{The Holocaust as Memory and Postmemory}

The next three poems, one by Yaoz-Keszt and two by Ági Mishol, feature secondgeneration sensations of children growing up in immigrant and Holocaust survivor families in the young State of Israel of the 1950s and 1960s.

"Shtikot" ['Silences']

[Dedication:] To my cousin Elizabeth, may her memory be blessed

The numerals on her arm have already faded

like tattoos on sailors' arms;

- For thirty-five years she decreed silence

on the story of the numerals on her arms, which begin with an "A"

so she could live the here-and-now

in the shadow of the sea, the home and the children,

and if she betrayed herself once in a while

it was only an incidental moving of the sleeve;

now five abandoned numerals in my mind refuse

to return to the silence of the multiplication-table.

(Yaoz-Keszt 1980: 37)

Yaoz Keszt's poem "Silences" is dedicated to his late cousin Elizabeth (which is probably a more international sounding translation choice of the poet for her Hungarian name Erzsébet), a survivor who tried to live a normal family life and raise carefree children "in the shadow of the [Mediterranean] sea." In fact, he means that his cousin lived under the mental shadow of her Central-European life and by the Middle-Eastern seaside, or that her memories of the earlier locale kept living with her in the later one although she tried to block their resurfacing. The Nazi camp inmates' tattoo on the cousin's wrist only occasionally surfaces from under her long sleeve, and when it does it attests also to her Hungarian-Jewish roots by the capital letter "A" that prefixes the "number" and which was common among Hungarian deportees to Auschwitz (on the Nazi camps' system of numbering inmates, see "Tattoos and Numbers - the System of Identifying Prisoners of Auschwitz," The Holocaust Encyclopedia, http://www.ushmm.org/wlc/en/article.php?ModuleId=10007056\#seealso).

Once Cousin Elizabeth died, the numerals are gone, too, and it is only their image as imprinted in the poet's memory that keeps reminding him of her suffering in the Holocaust. The poem's final lines, about the numerals" "refusal" to be tucked into whichever "multiplication table" or formula, carry the message that all that these specific numerals can stand for is but this one person. Thus the Nazi effort to turn human beings into inanimate items (stück in German), to dehumanize them by their serial numbering, is paradoxically and subversively converted in this poem into an act of pointing out the uniqueness of each and every victim as the only one that carries or carried her or his unique digit-combination. Following some of the discussions of the deeper meanings of the Nazi marking system in Amos Goldberg and Haim Hazan's co-edited essay collection Marking Evil: Holocaust Memory in the Global Age (2015), the Auschwitz "number" can be seen as a live "organ" that with time has become part of the person carrying it. Like the survivor, the "number," too, gets older, "fade[s] like tattoos on sailors' arms," and 
Rosen, Ilana. "The Poetry of 1.5 and Second-Generation Israelis of Hungarian Origin." Hungarian Cultural Studies. e-Journal of the American Hungarian Educators Association, Volume 8 (2015): http://ahea.pitt.edu DOI:

finally dies and disappears along with the survivor, its carrier or signified; thus death in old age becomes the ultimate rebellious act of those doomed to extermination decades earlier by the Nazi system and ideology.

An untitled poem by the third poet, Ági Mishol, exemplifies the concept and conception of "memorial candles," coined by psychotherapist Dina Vardi in her 1993 book by this title, in which she addressed the predicament of children born to survivors and, among them, those named after the parents' earlier children, or other family members, who were murdered in the Holocaust.

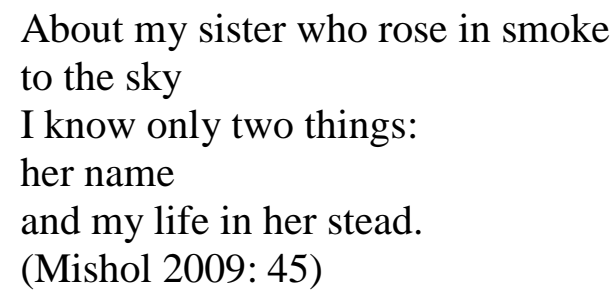

Considering the "[rising] in smoke to the sky" of the poet's older sister or half-sister, due to the late phase of World War II in which this fate befell Hungarian Jews, often, as described in their memoirs and oral testimonies, they could not or would not grasp in real time what really had happened to their beloved family members. In that situation, these ironic-sarcastic phrases became the answers they received from both veteran, non-Hungarian Jewish camp inmates and other camp functionaries of various identities, by way of so-called shock therapy.

Notwithstanding this historical explanation, the poet's partly childish partly mature phrasing also enables a naïve, fairytale-like understanding of her sister's fate as a disappearance into a fog or mist, as in a children's story.

In her reference to "only two things" she knows about her late sister, the poet alludes to the scarcity of information circulating in survivor families that on the one hand were too pained to be reminded of their lost loved ones, especially if they were children, and on the other could not let the memory of the lost sink into oblivion. Thus remembrance in this poem, like survival in Yaoz-Keszt's "Silences" poem, becomes a gesture of minimal action, rising just a bit beyond numbness as described in PTSD (Post Trauma Stress Disorder) therapy research, for example in Judith Lewis Herman's study (Herman 1992: 33-50), because more would be too difficult, too dangerous, or unbearable. To the same minimalist effect, Mishol does not disclose the name of her perished sister, which was apparently different from hers, thus clarifying that they belong to two different realities or worlds, as suggested also by the phrase referring to her living in her sister's stead, in literal Hebrew "place" (makom). The reference to place, in turn, evokes thoughts of contest or rivalry; one may think here of sports competition podiums as "places," or of families with more than a single child like the poet's family, with each child capturing a symbolic "place" of attention from their parents. If so, then the poet's capturing of her dead sister's place and obliteration of her existence by never even specifying her name is probably a source of guilt feelings, as grief, mourning, and mass-violence scholarships tell us (e.g.: Hass 1995: 163-183, Kaplan at www.aaets.org/article96). By contrast to how such a "memorial candle" child considers his or her own life in relation to a murdered sibling, from the point of view of Holocaust-bereaved parents, filling in the vacant place of the dead child with a new child is itself a victory vis-à-vis the Nazi perpetrators and their intention to wipe out the entire Jewish nation, including all generations. 
Rosen, Ilana. "The Poetry of 1.5 and Second-Generation Israelis of Hungarian Origin." Hungarian Cultural Studies. e-Journal of the American Hungarian Educators Association, Volume 8 (2015): http://ahea.pitt.edu DOI:

Ági Mishol's next untitled poem depicts the lives of Israeli survivor immigrants and their occasional social gatherings, in which they keep up their old country language and customs, while their children may be looking or listening and at any rate marveling at these revelations of their parents' past. Similarly, the well-known Israeli singer Hava Alberstein (b. 1947), who immigrated with her family at age three from Poland, devoted in 1986 an entire album, entitled Mehagrim ['Immigrants'], to such experiences and notions, wherein a song titled "Klafim al hamirpeset" ['Cards on the porch'] relates a scene that is much like the one in Mishol's next poem.

\author{
You think I am asleep already \\ but from the secret room I hear \\ the rummy in the front room. \\ Between the silences and claps of cards \\ you are again talking about the láger \\ of those who were in the láger \\ of those who were not in the láger \\ of those who returned from the láger \\ who talk about those \\ who did not return \\ from the láger.
}

(Mishol 2009: 43)

In this poem, the anaphoric German word lager, meaning Nazi concentration, work, or death camp, is a euphemistic term, similar to Hungarian phrases such as "a szegény" ['the poor one'], "nem jött vissza" ['did not return'], and "ott maradt/ak" ['remained there'] that were regularly used by Hungarian-Jewish Holocaust survivors wherever they lived. The foreign sounding and often repeated lager sounds to the little girl like part of the card game, when in fact, as she realizes as a grown-up poet well versed in shoah-avoidance terms and practices, this keyword is a reminder that underneath the seemingly pleasant pass-time gathering lie entire unfathomable depths of trauma and pain, which the survivors can only share amongst themselves; and that, too, only with the mediation of code words, which they cannot also entirely keep away from their children. Thus the lager keyword is a reminder that both sides - the speakers and the unintended listener eavesdropping from the "secret room"-resolve their traumas and communication hardships by tacit agreements about not pronouncing, not meaning, and never fully deciphering or entirely understanding the things (un)told.

\title{
Co-Fusion of Languages and Cultures
}

The next two poems, one by Mishol and one by Yaoz-Keszt, depict the eternal mental fidgeting between realities of those who were born or raised within Hungarian culture and then had to re-adjust to the Israeli and Middle-Eastern entirely new culture and its language in a general sense, including names, nicknames, tunes, sounds, and meanings.

"Bikur bayit" ['Home Coming']

On a Formica table

in a forty-page brown notebook made of non-wood fiber

I write: 
Rosen, Ilana. "The Poetry of 1.5 and Second-Generation Israelis of Hungarian Origin." Hungarian Cultural Studies. e-Journal of the American Hungarian Educators Association, Volume 8 (2015): http://ahea.pitt.edu DOI:

Ági Fried Gedera, Israel,

Asia, Earth, the Universe -

But the artery of flute-like emotion flows on

and its groundwater babbles in Hungarian:

Ági, Ágnes, Ágica, Áginka

What have you to do with the [Hebrew song] Sea of Sheaves all around.

(Mishol 2009: 31)

In this poem with the same title as her entire volume, Mishol journeys back to her school days in Israel of the mid 1950s, an era that was much the same for many hundreds of thousands of immigrant children of the time - whether they came from European or Middle-Eastern countries - that went through a unified, highly centralist, Zionist and socialist education system (see, for example, the 2010 study by Tali Tadmor-Shimony, historian of the 1950s and 1960s school curriculums). Middle aged native or almost-native Israelis of today, humorously calling themselves the "products" of that system, may easily recall the objects described in this poem, like the forty-page crude paper notebook, colored sand-brown in most cases and smelling like sandpaper. The same sense of "once was" is true concerning the Formica kitchen tables used by children for doing their homework in between meals. My personal childhood recollection of this period is of my mother's talking about a "Lakol asztal" ['Lakol table'] that my family had in another Jerusalem apartment, before I was born, and of me taking this word Lakol as either a kind of Formica, or as a foreign, probably Hungarian word; when in fact, as I found out years later, it was a trade-mark of simple, mass produced furniture of the time, whose meaning in simple Hebrew was "For All" ['lá-kol']; but the way my mom pronounced it did not sound Hebrew to me.

While Ági the small girl is doing her homework in a dull notebook in the frugal Israeli reality of the 1950s, her heart, ears, and inner self all long for the words, sounds, and sensations of her previous home at Szilágycheh, where she lived her formative first four or five years. This far-away reality, which is manifested by a mysterious, bewitching voice that she hears calling her, not only acknowledges her foreign sounding name, but also a whole chain of her old-country endearing nicknames like Ágica and Áginka; ironically, though, Mishol misspells her full first name Ágnes in Hebrew by ending it with an English "s" or Hungarian "sz" sounding consonant ["o," called 'samekh'] instead of, respectively, with an "sh" or "s" sound ["ש;" called 'sheen']. Finally, this other voice challenges her loyalty to the strict, highly-ideologist ethos of her new country; which, by the way, must have been even more authoritative in Romanian Chehu Silvaniei of that period, the 1950s, notwithstanding the poet's romantic, reminiscing longing for her late 1940s pre-communist and more Hungarian than Romanian past.

The focus or target of Mishol's anti-ideological rebellion in this poem is a popular Hebrew song of the early1970s, sung by a chorus called Gevatron, which was made up of amateur singers of the Jezreel Valley, including kibbutz and development-town people of various backgrounds, that often attached Hebrew rural-romantic, country-song lyrics to Russian folk tunes, and even dressed like Russian farmers in their shows. Ági the child as remembered by the grown up poet feels estranged from this ethos and its poetical and musical heritage, and instead turns to her inner world and to her Hungarian memories and roots, which are not specified in this poem but rather in another of her poems, the last that is analyzed in this article.

Like Ági Mishol, Itamar Yaoz-Keszt, too, wrote about the sound of his old name in the new country as a kind of return of the repressed. His experience is part of a dream in which he 
Rosen, Ilana. "The Poetry of 1.5 and Second-Generation Israelis of Hungarian Origin." Hungarian Cultural Studies. e-Journal of the American Hungarian Educators Association, Volume 8 (2015): http://ahea.pitt.edu DOI:

finds himself "walk[ing] half awake" in a typical 1950s or 1960s Middle-Eastern Israeli immigrant neighborhood, in a summer's heat spell or hamsin (in Arabic and Hebrew). This type of scenery to this day often goes together with loud Oriental music pouring out from the "throats," meaning the entrances, of ugly mass-housing, crowdedly populated apartment buildings from that period.

"Hashem hayashan" ['The Old Name']

I wanted to reach homeoutside of the circle of Middle-Eastern music

dripping from the throats of houses, as I walk half-awake, wondering how did I become part of this no-shadow landscape?

The afternoon heaviness bends the heads of grass between one pavement and the other and my head-

Only then did my ears hear my name called, from within sleep, and I also seemed to see my old name running along like a black cat through the alleys, over the facing walls of summer far from the houses holding on to me as with perpetually sweaty hands, and at my back - the porches on which sit-sit human-pajamas hunched over seemingly endless Shesh-Besh tables, in the shadow of a closed-eyes tuneThe cat looks from side to side in fervor, bending its head backwards as enticing with a child's cry through the broken window of my imagination in his steps to come on a day of heat wave visionsI saw that it was our old house cat, Among weeds it hopped by a well, and a howling voice comes from the well like a soul seeking its reform with no one around, only an erased name walking around in my steps, and I run, I still run homewards in front of the throats of houses that spit out my image with all the summer surpluses, in a sleepy Middle-Eastern tune. (Yaoz-Keszt 1976: 28-29)

In a dizzy-hazy state of mind, the poet hears his old name called out and he "also seem[s] to see [his] old name running along like a black cat through the alleys." This cat then passes by a well, 
Rosen, Ilana. "The Poetry of 1.5 and Second-Generation Israelis of Hungarian Origin." Hungarian Cultural Studies. e-Journal of the American Hungarian Educators Association, Volume 8 (2015): http://ahea.pitt.edu DOI:

which can hardly be part of the new Israeli immigrant towns with their modern water systems but which fits many a much older European small town or village, a setting that the poet would readily replace with his new "no-shadow landscape." The poem ends on a circular note, wherein the poet again roams the hot streets, trying to avoid the "sweaty" new locale where he started his Israeli life a quarter-century before writing this poem.

\section{The Eternal Mental Displacement of the Poets' Parents}

This last section deals with the poets' notions about the lives and experiences of their parents as forever uprooted immigrants, and in it I analyze one poem by Itamar Yaoz-Keszt, two poems by Dorit Weissman, and one by Ági Mishol. In the following untitled poem, Yaoz-Keszt writes about his father's hardships as a newcomer in quite a similar setting to that described in his "Old Name" poem.

It is a damp, neighborhood noontime-

my father sits at the dinner table,

he tastes the fruit of the Land for the first time,

the olives that send him

a dark and bitter look;

my father hesitates

but forces himself to reach out a hand

then forces his mouth to swallow the bitter dark ones

with their sharpened pits,

until suffocation

from the taste of the blackening fruit-

he spits out suddenly from inside him

the entire new country-

Hours

he stood at bus-stops, in the dissolving queue

in rain and shine,

mistaking the directions, fearing to be late-

only the bad poundings of his heart

running ahead of him,

the lack of language twitches between his lips

and squeezes his body

like pain-

(Yaoz-Keszt 1976: 38-39). 
Rosen, Ilana. "The Poetry of 1.5 and Second-Generation Israelis of Hungarian Origin." Hungarian Cultural Studies. e-Journal of the American Hungarian Educators Association, Volume 8 (2015): http://ahea.pitt.edu DOI:

This poem is sharply and visually — meaning in its stanza format — divided between two settings or scenes: an indoor, mealtime one and an outdoor, on-the-route recurrent scene of the father's painstaking bus rides accompanied by his agoraphobic fears of getting lost in the new, foreign country. In the first, indoor reality, the father, carefully scrutinized by his adolescent son, is trying to get used to the bitter taste - in both the literal and the figurative sense — of the new country and its olive fruit. Olives, a key component of Mediterranean cuisine, are experienced by this Central-European immigrant as a tasteless food of poverty. In ancient Jewish holy texts, the olive tree is one of the "seven kinds" (shivat haminim) by which the Land of Israel is blessed, along with wheat, barley, wine-tree, grenade-tree, fig-tree, and honey made of dates (Deuteronomy 8, 7-8); but for this immigrant, it is still an un-palatable, ugly fruit that literally aggravates his swallowing reflex.

Speaking of olives and European immigrants in Israel, folklorist Haya Bar-Itzhak has analyzed an anti-olive narrative she recorded among immigrants coming from Poland, following the so-called Gomulka late-1950s expulsion, who settled in Nazareth, in northern Israel, and experienced similar food bafflements as the Keszt father (Bar-Itzhak 2005: 63-64). In BarItzhak's work the tone of the narrative is light because the narrator, who initially took the olives to be plums, tells about it all retrospectively with humor and ease; whereas in this poem depicting the hardships of immigrants in real time as it were, the olives - with their dark color, bitter taste, and eventual spitting, or vomiting - emerge as repulsive and unbearable, and thus come to symbolize the entire reality of the new country. In the poem's second and last part, the poet describes his father's daily odyssey of roaming foreign streets and fearing of getting lost or being late, with his agony of disorientation magnified by his lack of language and limited ability to cope with stress due to his ailing, weak heart. Like his reaction to his olive meal, so his daily wanderings, too, exemplify how lost and displaced this middle-aged, Central-European, Holocaust survivor immigrant feels in his ancient new country.

The fourth and last poet that I will treat here, Dorit Weissman, wrote the following two poems in a volume depicting in poetry and short documentary notes her mother's fatal illness, Dorit's close support of her mother, and some rare moments in which the two got closer than ever before.

"Babushka"

The mother of the mother of my mother was hospitalized most of her life in Lunatic Asylums.

The mother of my mother did not hug, never asked how it was.

She yelled, according to my uncle, yelled all day, it was not easy: from a rich family to a life of poverty with five.

And my mother also did not hug me never, and I never saw her

excited as now in Erezbet [Erzsébet] Park

With yellow red leaves black trunks 
Rosen, Ilana. "The Poetry of 1.5 and Second-Generation Israelis of Hungarian Origin." Hungarian Cultural Studies. e-Journal of the American Hungarian Educators Association, Volume 8 (2015): http://ahea.pitt.edu DOI:

And all the years falling off her like leaves.

(Weissman 2005: 14)

In this poem, wrongly titled "Babushka" and meaning, in fact, matryoshka, which is the right name for the series of Russian wooden dolls packed within one another and symbolizing maternity and motherhood, Weissman, somewhat like Eli Netzer in his "The Existence of Man" poem, delineates her rather miserable family's ancestry. This family tree is full of poor, angry, and non-communicative women, just like their image in many East-European folk narratives rendering the lives of ordinary, lower class shtetl Jews, whose womenfolk could hardly offer and enjoy contact with their children, as repeated twice in this poem by the phrase "did not hug." Therefore, to hug, touch, and hold hands turns out to be Weissman's dear gift from and to her mother during the mother's last days and weeks. Within this reconciliatory state of things between them, the two of them travel to Hungary together and the daughter watches her mother enjoying her visit to the Budapest Erzsébet park (meaning "square" or "tér" in Hungarian), where she seems to become one with the autumn growth around her. The barren black trunks are there to remind us of the mother's closeness to death, but just before, she is granted the opportunity of turning the clocks back for a short while and enjoying the landscape of her youth, after decades of life far away from such sceneries.

The second Weissman poem takes its reader into the mother's Israeli home during the last fifty years of her life and into her kitchen, which used to be an ex-territory of Hungarian cuisine for Dorit and her only sister. Their mother would not let them into her world, either because she would not share her recipes, or she did not want her daughters to become too efficient housewives (as hinted by her own refusal to deal with dishwashing when tired from cooking), or maybe because her foreign tasting cooking was unappreciated by her Israeli children while they were growing up in a Middle-Eastern setting. One way or another, after their mother's death, the sisters have or want to learn their mother's Hungarian cooking from another woman, a relative or friend called Ilana.

"Paprikás ve [and] Gombóc, Nudli ve [and] Nokerli [Nokedli]"

You never taught us to cook

or even to chop an onion

and after your death, with Ilana,

we learn paprikás and gombóc, nudli and nokerli [nokedli]

and how to leave a clean kitchen.

With you all the dishes piled up in the sink.

You finished cooking, left it all there, tired, went to bed, no one tells

me what to do, when I wake up I will tidy up

and you also used to say

that the chicken cooks in its own juice. (Weissman 2005: 12) 
Rosen, Ilana. "The Poetry of 1.5 and Second-Generation Israelis of Hungarian Origin." Hungarian Cultural Studies. e-Journal of the American Hungarian Educators Association, Volume 8 (2015): http://ahea.pitt.edu DOI:

The dishes that the two sisters learn to prepare are everyday nourishing Hungarian foods nowadays craved by most grown-up Hungarian-Israelis and probably by many other people of Hungarian origin all over the world. In addition, at least the last three of the foods listed in this poem involve kneading, rolling, and making all kinds of forms from dough, which again refers to the senses of touch and contact that are so central because so rarely expressed in this family. But this Ilana teaches the orphaned sisters another thing, which their mother likewise never taught them, nor implemented herself, and that is the "art" of kitchen cleanliness, or rather the façade that an active, servicing kitchen can also be always kept clean. The mother's rebelliousness in this regard may give us a hint as to her free spirit and housekeeping style as well as, probably, to her long widowhood, without a soul "telling [her] what to do." Finally, the poet daughter is reminded not only of her mother's Hungarian delicacies but also of one of the mother's so-called culinary sayings, that is, that "the chicken cooks in its own juice." This explicitly amusing and implicitly bitter-ish saying hints at the mother's tendency to keep her trouble and secrets all to herself instead of sharing them with anyone and especially her two daughters, which, again, may also explain Dorit's joy at being finally close to her mother during the mother's last illness.

Last in my analysis is an untitled poem written by Ági Mishol and addressed to her mother, whom she admired for many reasons, including the mother's legacy of resilience and joy despite or in the face of her life's agonies.

You [female: $\bar{a} t$ ] taught me to recite in German

"The Forest Minister" [Germ. 'Erlkönig'] and play on the piano "The Acacia Path" [Hung. 'Akácos út'] on which every Hungarian strolled.

You taught me a basting stitch, to iron, and all the prepositions in Latin that you managed to learn before they took you away.

You did not know any stories but we laughed a lot over obscene jokes that were turned into children tales and you remembered one Grimm's tale.

You taught me to ride a bicycle and all the Operettas from the gay Vienna days, and you, who had a "weak organism"[taught me] the abyss of perforated grief because of which for me everything always will be just fine.

(Mishol 2009: 59)

This poem delineates a long list of Central-European cultural treasures, as well as a few feminine household skills, which the poet's mother taught or passed on to her. The first two of these are poetical and musical works; one is Johann Wolfgang von Goethe's German ballad "Erlkönig" ['Erlking,' 'Erl-King,' or 'Alder King'; translated into Hebrew by several translators as "Sar hayaar," 'The Forest Minister'], and one is a Hungarian folk song composed by Jakob Pazeller (1869-1957). Both these gloomy, romantic texts and their recitations or singing by the mother and daughter symbolize their clinging to the Central-European culture with which the mother 
Rosen, Ilana. "The Poetry of 1.5 and Second-Generation Israelis of Hungarian Origin." Hungarian Cultural Studies. e-Journal of the American Hungarian Educators Association, Volume 8 (2015): http://ahea.pitt.edu DOI:

had to part in her youth. Later in the poem there are also allusions to Viennese operettas and through them to quite a few well-known European Jewish (or of Jewish origin) composers of the nineteenth and twentieth century, like Johann Strauss Jr. (1825-1899), Jacques Offenbach (18191880), and Emerich (Imre) Kálmán (1882-1953). For the mother all these belong to an era that once was and which she hardly enjoyed because of the catastrophes that befell European Jewry, yet she lives up to its memory and aura for decades afterward and despite painful disillusionment.

The allusion to the family piano in this poem is important because owning a piano in the frugal Israeli reality of the 1950s attests to a relatively convenient financial state of the owners as well as to their bourgeois refinement or aspirations; accordingly, in addition to poetry recitations and piano recitals, this mother also teaches her daughter simple household skills like basting stitches and ironing, as well as some Latin, a language which neither then nor nowadays could be of much use around Gedera. While all these issues of "fashioning a lady" out of this mother's daughter are dealt with in detail, the horrors of the Holocaust and the suffering of the mother and many other Jews of her generation are but hinted at, without specifying, for example, who are the ones who "took [the mother] away" before she could complete her knowledge of Latin, where to, and why. The poet then returns to her mother's bygone repertoire of a few obscene jokes related to some nineteenth century Grimm Brothers fairytales, thus strengthening the mother-anddaughter's bond, which is obviously a no-man's land in this poem, where no father is ever mentioned, just as there is no mention of a father anywhere in Dorit Weissman's entire poetry volume. The following reference to bicycle riding and to the mother's teaching this physical skill, too, to her daughter further fortifies their feminine duo.

If all these mother-and-daughter quality-time activities might lead us readers to think that this mother and her single daughter had a perfect life together, in comes, or sneaks, the early-mid twentieth century European literary trope of the tendency toward physical-mental-emotional feebleness, here alluded to by the vague phrase "weak organism," which is the furthest the poet can go by way of alluding to the ultimate source of trauma in her mother's life, the Holocaust. Whatever its background, this trait of the mother lets in another, less vital and cultural or refined part of her life and psyche besides poetry and piano recitations, bicycle rides, and naughty jokes and tales. Unlike the specificity and liveliness of all those other activities and legacies, here the poet resorts to a general, metaphorical phrasing when relating to "the abyss of perforated grief" that exists deep down in her mother's soul, underneath her liveliness and treasures of knowledge and skills. If all the other traits helped the mother raise a competent, educated, and merry child, then this "abyss" adds its part by making the grown-up daughter, well, not ever happy and content, but rather declare that "for [her] everything is always just fine," even when it is not. Thus the real legacy that is passed on between this trauma stricken mother and her seemingly lively daughter is one of holding on to poetry, music, culture, some practical skills, humor, and family; but, or while never expressing any other needs, or calls, or cries, lest the fine, romanticized picture of the mother-and-child's glass porch - to summon an image from YaozKeszt's "Route Preparations" poem — be smashed and smeared with blood and tears, or even just cracked.

To conclude, in this article I have offered a reading in eleven poems written in the last four decades by four 1.5 and second-generation Israeli poets of Hungarian origin, partly continuing my previous work on the biographically determined prose works of a few other Israeli authors of Hungarian origin. The preceding analyses show that like the prose works of this group, its poetry, too, is preoccupied with the experiences and imprints of the Holocaust, 
Rosen, Ilana. "The Poetry of 1.5 and Second-Generation Israelis of Hungarian Origin." Hungarian Cultural Studies. e-Journal of the American Hungarian Educators Association, Volume 8 (2015): http://ahea.pitt.edu DOI:

immigration and loss of language, and of the figures of the parents of these poets as people scarred by shattering experiences who nevertheless managed to pass on to their children at least some of their past, beloved Hungarian legacies. Compared with the prose works of this group, these poems come up as, surprisingly or not, less gloomy, pessimistic, accusing, and pained. Perhaps because poetry, as opposed to prose, is lyrical, subjective, and fragmentary by nature, it can more easily distill the national, communal, familial and parental experiences and mold them into personal poetic expression, which is free of the commitment to narrative chronology and historical reason. Poetry can afford to let go of what may be factual but trivial, or too painful, in favor of more concise, carefully chosen, bearable, and reconciled stories and messages, the ones that the poets are more willing to live with and pass on to their audiences and — possibly—future generations of readers.

\section{Works Cited}

Adorno, Theodore W. 1967. "Cultural Criticism and Society." Prisms (trans. Samuel and Sherry Weber). Cambridge, MA: MIT Press.

Alberstein, Hava. 1986. Mehagrim ['Immigrants'] (music album).

Bar-Itzhak, Haya. 2005. Israeli Folk Narratives: Settlement, Immigration, Ethnicity. Detroit, MI: Wayne State UP.

Fuchs, Esther. 2000. "Second-Generation Poetry in Hebrew." Shofar 18.3: 64-76.

Galron-Goldschlager, Joseph, Ed. in Chief. Lexicon hasifrut haivrit hahadasha ['Lexicon of Modern Hebrew Literature']. Ohio State University, at: http://library.osu.edu/projects/hebrew-lexicon

Goldberg, Amos and Haim Hazan. 2015. Marking Evil: Holocaust Memory in the Global Age. UK: Berghahn Books.

Hass, Aaron. 1995. "Survivor Guilt in Holocaust Survivors and their Children." A Global Perspective on Working with Holocaust Survivors and the Second Generation. Ed. John Lemberger. New York: Schocken Books: 163-183.

Herman, Judith Lewis. 1992. Trauma and Recovery: The Aftermath of Violence from Domestic Abuse to Political Terror. New York: Basic Books.

Hirsch, Marianne. 2012 The Generation of Postmemory: Writing and Visual Culture after the Holocaust. New York: Columbia UP.

The Holocaust Encyclopedia, the United States Holocaust Memorial Museum http://www.ushmm.org/wlc/en/article.php?ModuleId=10007056\#seealso

Kaplan, Fara. "Holocaust Survivors and their Children: A Search for Positive Effects." American Academy of Experts in Traumatic Stress, AAETS www.aaets.org/article96

Mishol, Ági. 2009. Bikur bayit ['Home Coming']. Tel Aviv: Hakibbutz Hameuchad.

Netzer, Eli. 1992. Be-erets hagoral ['In the Land of Fate']. Kibbutz Dalia: Ma'arechet.

Rosen, Ilana. 2014. "Fragments of a Hungarian Past in the Literature of 1.5 and Second-Generation Austro-Hungarian Immigrants in Israel." Hungarian Cultural Studies 7: 1-13. http://ahea.pitt.edu/ojs/index.php/ahea/article/view/138.

Stavi, Zissi and Yigal Schwartz, eds. 2014. Lexicon heksherim lesofrim yisraelim ['The Heksherim Lexicon of Israeli Authors']. Beer Sheva and Or Yehuda: Heksherim Institute at Ben Gurion University of the Negev and Kineret, Zmora-Bitan, Dvir Publishers. 
Rosen, Ilana. "The Poetry of 1.5 and Second-Generation Israelis of Hungarian Origin." Hungarian Cultural Studies. e-Journal of the American Hungarian Educators Association, Volume 8 (2015): http://ahea.pitt.edu DOI:

Suleiman, Susan Rubin. 2002. “The 1.5 generation.” American Imago 59.3: 277-295.

Tadmor-Shimony, Tali. 2010. Shiur moledet - hinukh leumi uvinuy uma beyisrael 1954-1966 ['National Education and State Formation in Israel 1954-1966']. Sde Boker: the Ben Gurion Research Institute for the Study of Israel and Zionism, Achva Academic College.

Vardi, Dina. 1993. Memorial Candles: Children of the Holocaust. London: Tavistock/Routeledge.

Vardi, Dov. 1981. "On Four New Volumes of Poetry: Itamar Yaoz-Keszt's The Smelter of Identities." Modern Hebrew Literature 6.3-4: 66-69.

Weissman, Dorit. 2005. Lirkod itach csárdás - preda me-em ['Dancing Csárdás with You: Poems Parting from a Mother']. Ra'anana: Even Hoshen.

Yaoz, Hannah. 1984. Hashoah beshirat dor hamedina ['The Holocaust in the poetry of the Statehood of Israel Generation']. Tel Aviv: Eked.

Yaoz-Keszt, Itamar. 1976. Du-shoresh - shirim veshirim beproza ['Double/Dual Root Poems and Prose-Poems']. Ramat Gan: Eked.

Yaoz-Keszt, Itamar. 1980. Matikh-hazehuyot ['The Smelter of Identities']. Tel Aviv: Eked. 